\title{
Seabirds and marine mammals redistribute bioavailable iron in the Southern Ocean
}

\author{
S. R. Wing ${ }^{1, *}$, L. Jack1 ${ }^{1}$, O. Shatova ${ }^{1}$, J. J. Leichter ${ }^{2}$, D. Barr ${ }^{3,4}$, R. D. Frew ${ }^{3}$, \\ M. Gault-Ringold ${ }^{3}$ \\ ${ }^{1}$ Department of Marine Science, University of Otago, PO Box 56, Dunedin, New Zealand 9054 \\ ${ }^{2}$ Scripps Institution of Oceanography, 9100 Gilman Drive, University of California at San Diego, San Diego, California 92093, USA \\ ${ }^{3}$ Department of Chemistry, University of Otago, PO Box 56, Dunedin, New Zealand 9054 \\ ${ }^{4}$ Otago Centre for Trace Element Analysis, University of Otago, PO Box 56, Dunedin, New Zealand 9054
}

ABSTRACT: Biological vectors are important for redistribution of nutrients in many ecological systems. While availability of iron (Fe) to phytoplankton limits pelagic productivity in the Southern Ocean, biomagnification within marine food webs can lead to high concentrations of $\mathrm{Fe}$ in the diet of seabirds and marine mammals. We investigated patterns in concentrations of the micronutrients $\mathrm{Fe}$, $\mathrm{Co}, \mathrm{Zn}$ and $\mathrm{Mn}$, and the toxins $\mathrm{Cd}$ and $\mathrm{As}$, in the guano of oceanic, coastal and predatory seabirds and in faeces of 2 species of marine mammals that congregate to breed in the sub-Antarctic Auckland Islands. We found that much of the variability in concentrations of $\mathrm{Fe}, \mathrm{Co}, \mathrm{Zn}$ and $\mathrm{Mn}$ among species could be explained by foraging behaviour and by trophic position. We observed concentrations of $\mathrm{Fe}$ to be 8 orders of magnitude higher in the guano of predators and coastal foragers than in the sub-Antarctic mixed layer. High concentrations of As and $\mathrm{Cd}$ were associated with organic matter sources from macroalgae. Analyses of the molar ratio $\mathrm{Fe}: \mathrm{Al}$ indicated that $\mathrm{Fe}$ within food webs supporting seabirds has likely been extensively recycled from its lithogenic source. Patterns in Fe:N among species indicated that $\mathrm{Fe}$ is concentrated 2 to 4 orders of magnitude in the guano of seabirds compared to limiting conditions for phytoplankton growth in sub-Antarctic waters. These data highlight the potential role of seabirds and marine mammals in the redistribution of micronutrients in the Southern Ocean and their likely role as key nutrient vectors in the ecosystem, particularly around the sub-Antarctic islands during the breeding season.

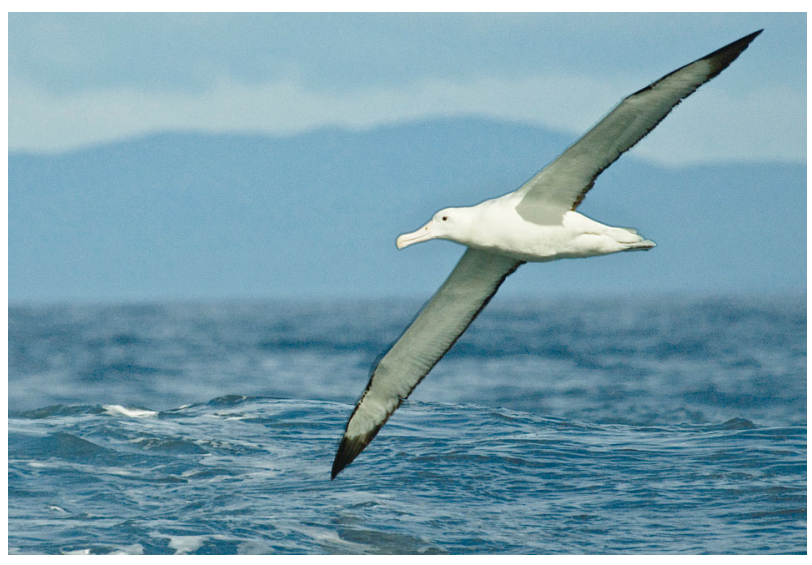

Seabirds such as the albatross Diomedea epomophora are important nutrient vectors in the Southern Ocean.

Photo: S. Wing

KEY WORDS: Fe - Micronutrient - Sub-Antarctic · Biological vector · Trophic position · Primary productivity

Resale or republication not permitted without written consent of the publisher

\section{INTRODUCTION}

Biological vectors of limiting nutrients can reshape patterns in productivity and underpin ecosystem stability on broad geographic scales linking aquatic and terrestrial environments (Meyer \& Schultz 1985, Polis \& Hurd 1996, Post et al. 1998, Helfield \& Naiman 2001, Wolf et al. 2013). Consequently, loss of 
key nutrient vectors through extinction or population decline may have dramatic effects on system productivity (Doughty et al. 2013). In the marine environment, the redistribution of macronutrients by seabirds and marine mammals (e.g. Sánchez-Piñero \& Polis 2000, Hawke \& Holdaway 2005, Nicol et al. 2010) highlights vital structural mechanisms for ecological connectivity (Polis et al. 1997, McCauley et al. 2012). These studies illuminate the role of high trophic level consumers as important biological vectors of nutrients within the coastal environment and across ecotone boundaries. For example, the loss of seabirds on islands with introduced arctic foxes in the Aleutian archipelago has resulted in a striking transformation of plant communities, a trophic cascade not driven by direct population regulation, but by top-down influences on nutrient supply (Croll et al. 2005). While the majority of studies of seabirds as biological vectors have focussed on the supply of macronutrients ( $\mathrm{N}$ and P) near breeding colonies, seabirds are also effective vectors of essential micronutrients ( $\mathrm{Fe}, \mathrm{Co}, \mathrm{Mn}, \mathrm{Zn})$ as well as bioactive trace metals such as $\mathrm{Hg}, \mathrm{Cd}$ and As. Consequentially, seabirds have long been used as biological indicators for accumulation of heavy metals within food webs (Norheim 1987, Lock et al. 1992). For example, seabird rookeries in the high Arctic have been linked to accumulation of toxic concentrations of heavy metals in lakes (Evenset et al. 2007, Keatley et al. 2009). In the present study, we investigated the potential role of seabirds and marine mammals as vectors for the essential micronutrients Fe, $\mathrm{Co}, \mathrm{Mn}$ and $\mathrm{Zn}$ in the high-nutrient low-chlorophyll (HNLC) waters of the New Zealand sub-Antarctic region in the Southern Ocean.

In the Southern Ocean, the availability of Fe limits pelagic productivity (La Roche et al. 1996, Behrenfeld \& Kolber 1999), leading to HNLC conditions. In situ experimental additions of soluble Fe, applied at low $\mathrm{pH}$, have resulted in phytoplankton blooms, indicating that $\mathrm{Fe}$ plays a vital role in the carbon (C) cycle of the region (Boyd et al. 2007). These diatomdominated blooms typically become silicate-limited in high nitrate conditions, leading to a differential effect of Fe in high- versus low-Si waters (Coale et al. 2004). Sustained productivity has been observed in the wakes of islands, regions in which persistent eddies form leeward of a prevailing current, where Fe and Si may be replenished by runoff from multiple terrigenous sources (Blain et al. 2007, 2008). Thus primary productivity in HNLC conditions may respond to vectors of Fe supply, such as wind-blown dust (Mackie et al. 2008), riverine inputs and coastal upwelling (Blain et al. 2007). However, Fe supplied directly from lithogenic sources becomes insoluble at $\mathrm{pH}>4$ and is therefore not readily available to phytoplankton (Jickells et al. 2005). Indeed, the high productivity observed in island wakes is not well correlated with total particulate Fe concentration (Blain et al. 2001, 2008). Recent work on dust indicates that this direct lithogenic source only leads to small increases in the dissolved Fe mixed-layer inventory (Boyd et al. 2010). Nevertheless soluble Fe, sulphurFe proteins and haem molecules are available for recycling in the microbial loop of deep pelagic systems, resulting in high retention of Fe in the pelagic food web (Boyd et al. 2004, Frew et al. 2006). These results suggest that a significant proportion of the Fe that sustains pelagic productivity under HNLC conditions may be sourced or recycled from within the food web from biological vectors (e.g. Nicol et al. 2010).

Food consumption by the world's seabirds is approximately 96.4 $\mathrm{Mt} \mathrm{yr}^{-1}$ (Brooke 2004, Karpouzi et al. 2007), comparable to the biomass removed by

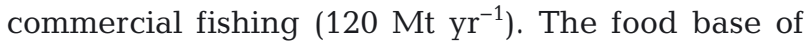
commercial fishing comprises approximately $8 \%$ of global ocean primary production (Pauly et al. 2002). An important distinction is that while fisheries remove nutrients from oceanic systems, seabirds recycle them. Of the worldwide consumption by seabirds, $54 \%$ comprises Fe-rich krill (Nicol et al. 2010) and cephalopods (Brooke 2004). Here, $75 \%$ of the top consumers of these species are exclusive to the Southern Ocean (Brooke 2004). In this context, the sub-Antarctic islands are global hotspots for seabird diversity and prey consumption (Karpouzi et al. 2007).

Diving seabirds rely on high blood volume and high concentrations of Fe-rich haemoglobin and myoglobin to maintain their dives (Kooyman \& Ponganis 1998) and all seabirds have vital metabolic needs for Fe. Excess Fe from diet and sloughed cells is egested in guano, which when combined with urine excreted at low pH (Long \& Skadhauge 1983, Bernardi et al. 2009) enhances the solubility of Fe. Several examples of how seabirds enhance productivity on land (Sánchez-Piñero \& Polis 2000), in the intertidal (Bosman et al. 1986) and in freshwater (Keatley et al. 2009) highlight the potential importance of their role as a vector for nutrient supply. Thus seabirds, when aggregated at high density, are potentially an important node in micronutrient cycles and a key component of the $\mathrm{C}$ cycle in the vicinity of the sub-Antarctic islands.

In the present study, we compared concentrations of $\mathrm{Fe}, \mathrm{Co}, \mathrm{Zn}, \mathrm{Mn}, \mathrm{Cd}$ and As among fresh samples of guano from 6 species of seabirds, representing 3 
basic foraging guilds: oceanic, coastal and predatory. We compared these concentrations with those found in the faeces of 2 species of marine mammal that congregate to breed at the Auckland Islands. Further, we used analysis of $\delta^{13} \mathrm{C}$ and $\delta^{15} \mathrm{~N}$ to quantify the trophic level and composition of organic matter sources fuelling the food webs that support each seabird and marine mammal species. Using these 2 metrics, we estimated the 'trophic position' of each species within the sub-Antarctic food web. Analysis of the molar ratio of $\mathrm{Fe}: \mathrm{Al}$, which increases with biological recycling of $\mathrm{Fe}$ at each trophic step from the lithogenic source (Frew et al. 2006), was used to infer the relative degree of recycling within specific food webs associated with each foraging guild. Together, these data offer a first account of the likely position of seabirds and marine mammals within the micronutrient dynamics of sub-Antarctic island food webs and describe the likely links between foraging strategy and potential for redistribution of micronutrients $(\mathrm{Fe}$, $\mathrm{Co}, \mathrm{Zn}, \mathrm{Mn}$ ) and toxins ( $\mathrm{Cd}$ and As) within the coastal system. Technical advances in tracing sources of organic matter and trace elements in food webs allowed us to resolve nutrient flux and bioaccumulation in these systems and to begin to address the question: What is the potential for seabirds and marine mammals to redistribute Fe and other micronutrients in the vicinity of the sub-Antarctic islands?

\section{MATERIALS AND METHODS}

\section{Focal species}

\section{Oceanic foragers}

Seabirds common to the Auckland Islands such as southern royal albatross Diomedea epomophora forage widely from food webs over vast pelagic areas of the Southern Ocean, extending 2000 to $8000 \mathrm{~km}$ from their nesting sites (Waugh et al. 2005). These species forage on spawning aggregations of squid, and opportunistically feed on surface aggregations of mesopelagic fishes and euphausiids, with a primary diet linked to the pelagic food web of the shelf break (Imber 1999). A significant portion of diet may be scavenged from the mesopelagic fishing industry and from feeding aggregations of marine mammals (Waugh et al. 2005).

The yellow-eyed penguin Megadypes antipodes makes extensive foraging trips to the outer continental shelf and slope and feeds extensively on pelagic fishes such as sprat Sprattus antipodum and on squid
Nototodarus sloanii with limited feeding on benthic species such as red cod Pseudophycis bachus (van Heezik 1990).

\section{Coastal foragers}

The endemic Auckland Island shag Phalacrocorax colensoi is restricted to the island region and its associated food webs. These cormorants make foraging trips out across the island wake onto the shelf, feeding on a variety of prey including octopus Octopus huttoni, small schooling fish such as red cod and benthic fish including triplefins (Tripterygiidae; C. Lalas unpubl. data).

Black-backed gulls Larus dominicanus are primarily coastal feeders, breaking open shellfish, foraging in the intertidal and opportunistically feeding on carrion. In the Auckland Islands, the mussels Aulacomya maoriana and Mytilus galloprovincialis, limpets Patella magellanica, chitons Chiton lineolatus and majid crabs make up a large portion of black-backed gull diet (S. Wing unpubl. data), suggesting strong links to the coastal intertidal food web.

\section{Predators}

The brown skua Catharacta skua is a predator of other seabirds (Pietz 1987). On the Auckland Islands, brown skua feed on chicks of Auckland Island shag P. colensoi, diving petrels (e.g. Pelecanoides urinatrix) and prions (Pachyptila spp.), as well as on carrion, primarily Hooker's sea lions Phocarctos hookeri and Australasian fur seals Arctocephalus forsteri (S. Wing unpubl. data).

Northern giant petrels Macronectes halli feed on a range of marine life including fledgling seabirds and scavenge extensively on carrion (Ridoux 1994). In the Auckland Islands, they focus strongly on carrion of Hooker's sea lions and Australasian fur seals, but also feed in the island wake on zooplankton, mesopelagic fish and squid (S. Wing unpubl. data).

\section{Marine mammals}

The Hooker's sea lion (classified as 'nationally critical' by the New Zealand Department of Conservation) has a remnant breeding colony on the Auckland Islands (Childerhouse \& Gales 1998). Diet includes coastal fish and invertebrates as well as mesopelagic fish and squid, and the sea lions can be found as far 
north as the Subtropical Convergence on foraging bouts (Lalas 1997). Hooker's sea lions also feed on Australasian fur seals (L. Jack unpubl. data).

Southern right whales Eubalaena australis congregate to breed at the Auckland Islands where they form a dense aggregation in winter. Whales feed primarily on lobster-krill Munida gregaria, copepods (Calanus spp.) and euphausiids including Euphausia superba and concentrate their feeding on the Subtropical Convergence (Best \& Schell 1996). The Subtropical Convergence, a major division between macronutrient-limited subtropical and micronutrient-limited sub-Antarctic water masses, lies to the north of the Auckland Islands where it follows shelf bathymetry (Smith et al. 2013).

\section{Sample collection}

We collected individual samples of fresh guano in January 2011 from occupied nesting and rookery sites of each species. In each case, positive matches were made between individuals of each species and the guano sample collected. Guano samples were collected using trace element clean procedures into acidwashed vials and frozen for later analysis. Samples of southern right whale faeces were collected during July 2011 and July 2012 from breeding aggregations of whales in Ross Harbour. Individual samples were collected with a fine-meshed dip net and transferred into clean sample containers. Samples of Hooker's sea lion faeces were collected in January 2011 from haulout sites on Enderby Island and Auckland Island, again matched to individual animals. Each sample was collected using trace element clean sampling procedures into acid-washed vials and stored frozen for later analysis. From these samples, 6 to 12 replicates of each species were then prepared for analysis of $\delta^{13} \mathrm{C}$ and $\delta^{15} \mathrm{~N}$ by isotope ratio mass spectrometry and trace elemental concentration by inductively coupled plasma mass spectrometry (ICP-MS).

\section{Stable isotope analysis}

Samples were freeze-dried and ground to a fine powder using mortar and pestle. From each sample, a 1 to $2 \mathrm{mg}$ subsample was weighed, depending on sample type, and sealed into a tin capsule for stable isotope analysis of $\delta^{13} \mathrm{C}$ and $\delta^{15} \mathrm{~N}$. Samples were analysed in the Department of Chemistry, University of Otago, by combustion in an elemental analyser (Carlo Erba NA1500) to $\mathrm{CO}_{2}$ and $\mathrm{N}_{2}$. The isotopic compositions of the sample gases were measured by a Delta Advantage isotope ratio mass spectrometer (Thermo-Finnigan) operating in continuous flow mode. Raw delta values were normalized and reported against the international scales for C and N, Vienna PeeDee Belemnite and air, respectively. Normalization was made by 3-point calibration with 2 glutamic acid international reference materials and a laboratory EDTA (Elemental Microanalysis) standard for C (USGS- $40=-26.2 \%$, USGS-41 $=37.8 \%$, EDTA $=-38.52 \%$ ) and N (USGS$40=-4.52 \%$, USGS- $41=47.57 \%$, EDTA $=-0.73 \%$ ) . Time-based drift correction was calculated from the laboratory standard analysed at regular intervals with the samples. Analytical precision based on the replicate analyses of the quality control standard (EDTA, $\mathrm{n}=12$ ) was $0.2 \%$ for $\delta^{13} \mathrm{C}$ and $0.3 \%$ for $\delta^{15} \mathrm{~N}$.

\section{Trophic position using isotopic mixing models and trophic level}

$\delta^{13} \mathrm{C}$ and $\delta^{15} \mathrm{~N}$ of phytoplankton was characterised by sampling suspended particulate organic matter (SPOM) with a $20 \mu \mathrm{m}$ mesh plankton net from 9 sites surrounding the Auckland Islands and calculating a stratified mean (Fig. 1). $\delta^{13} \mathrm{C}$ and $\delta^{15} \mathrm{~N}$ of

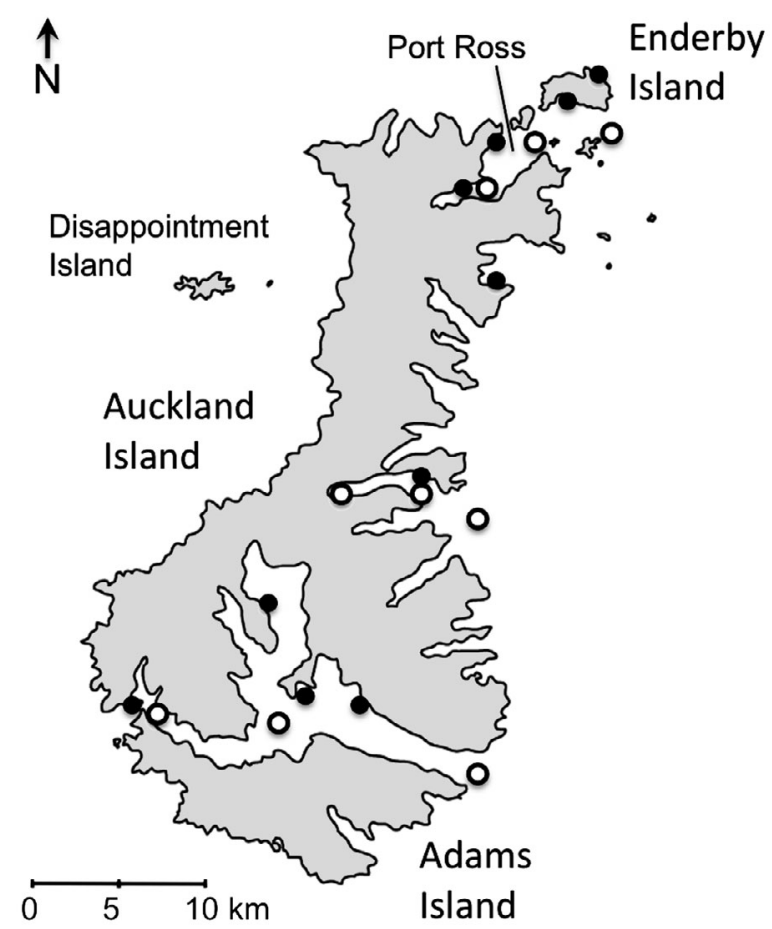

Fig. 1. Field sites on the Auckland Islands, New Zealand. $(\bullet)$ collection sites for macroalgae and guano; (o) collection sites for suspended particulate organic matter 
macroalgae were characterised with a stratified mean from samples of Macrocystis pyrifera and Durvillaea antarctica collected from each shore station (Fig. 1).

An iterative procedure was then used to determine the basal organic matter used and the trophic level of the diet of each seabird and marine mammal. Firstly, the relative contribution of SPOM and macroalgae was estimated for each individual using $\delta^{13} \mathrm{C}$ in a 2 -source mass balance model (Phillips \& Gregg 2001, Jack \& Wing 2011). In this step, an approximation of trophic level was used to estimate trophic discrimination of $\delta^{13} \mathrm{C}$. The results of this model were used to estimate the corresponding $\delta^{15} \mathrm{~N}$ of the mixture of organic matter sources supporting each individual $\left(\delta^{15} \mathrm{~N}_{\text {base }}\right)$. Trophic level was then calculated for each individual from $\delta^{15} \mathrm{~N}_{\text {base }}$ defined as: $\left(\delta^{15} \mathrm{~N}_{\text {consumer }}-\delta^{15} \mathrm{~N}_{\text {base }} / \Delta_{\mathrm{n}}\right)+1$, where $\Delta_{\mathrm{n}}$ is the trophic discrimination factor, after Post (2002). The resulting estimate of trophic level was then iterated back into the mass balance model until a stable solution was obtained for both the mixture of organic matter sources and trophic level. We used the average trophic discrimination factors for aquatic environments of $+0.4 \%$ (SE 0.17) for $\Delta^{13} \mathrm{C}$ and $+2.3 \%$ (SE 0.28 ) for $\Delta^{15} \mathrm{~N}$, after McCutchan et al. (2003), for each enrichment step.

\section{ICP-MS methods}

Samples of seabird guano and marine mammal faeces were freeze dried in acid-washed high-density polyethylene (HDPE) vials. Each sample was then ground into a fine powder using acid-washed HDPE rods. A $0.2 \mathrm{~g}$ aliquot of each sample was then cold digested using $10 \mathrm{ml}$ quartz-distilled (QD) $\mathrm{HNO}_{3}$ for $1 \mathrm{~h}$ in acid-washed perflouroalkaloxy CEM microwave tubes, then hot digested in a CEM MARS6 microwave at $180^{\circ} \mathrm{C}$ for $40 \mathrm{~min}$. When cooled, digested samples were dried down on a hot block and re-dissolved using $1 \mathrm{ml} \mathrm{QD} \mathrm{HNO}_{3}$, diluted up to $25 \mathrm{ml}$ using MilliQ filtered water and then further diluted 10:1 using MilliQ.

An Agilent 7500ce quadrupole ICP-MS with octopole collision cell and autosampler was used for the analysis of trace metals in guano and faeces samples. $\mathrm{Al}, \mathrm{Fe}, \mathrm{Zn}, \mathrm{As}, \mathrm{Cd}$ and Co were of primary interest, but other elements were measured to establish matrix composition and possible interferences. Dilutions of the sample digests and blanks in $2 \% \mathrm{v} / \mathrm{v} \mathrm{HNO}_{3}$ were spiked offline with a cocktail of 6 reference elements to compensate for any drift or possible matrix effects.
Calibration standards were prepared by serial dilution of a SPEX CertiPrep multi-element standard (NIST traceable). The ICP-MS was tuned according to the manufacturer's recommendations for robust conditions to minimize interferences and instrumental drift. Where possible, multiple isotopes of the analyte elements were measured to confirm the absence of interferences. The accuracy of this single step measurement was established with several Certified Reference Materials (DOLT-2 dogfish liver, National Research Council Canada; CRM-414 plankton, Institute for Reference Materials and Measurements, IRMM; CRM BCR-279 sea lettuce, IRMM). The analysis of microwave-assisted digestions of 3 biological reference materials for the elements of interest gave recoveries typically within $5 \%$ of expected values, while the digestion of a mineral reference material produced recoveries within $2 \%$ of certified values.

\section{Statistical analysis}

Three seabird foraging guilds were determined $a$ priori based on each species' foraging behaviour, and compared to a fourth group made up of marine mammals. Oceanic foragers included the southern royal albatross and yellow-eyed penguin, coastal foragers comprised the black-backed gull, red-billed gull and Auckland Island shag. Predators comprised brown skua and northern giant petrel, and marine mammals comprised Hooker's sea lion and southern right whale. We used ANOVA to test variance of $\delta^{13} \mathrm{C}, \delta^{15} \mathrm{~N}, \mathrm{Fe}$, $\mathrm{Co}, \mathrm{Fe}: \mathrm{Al}, \mathrm{Fe}: \mathrm{C}, \mathrm{Fe}: \mathrm{N}, \mathrm{Zn}, \mathrm{Mn}$, As and Cd with species (fixed, 8 levels, except $\delta^{13} \mathrm{C}, \delta^{15} \mathrm{~N}$ : fixed, 9 levels), nested within foraging guild (fixed, 4 levels) (JMP Pro 10, SAS). Samples from red-billed gull Chroicocephalus scopulinus, a coastal forager, were analysed for $\delta^{13} \mathrm{C}$ and $\delta^{15} \mathrm{~N}$ only. In addition, we tested for linear relationships between $\delta^{13} \mathrm{C}, \delta^{15} \mathrm{~N}$ and each of the trace metal concentrations (JMP Pro 10, SAS).

\section{RESULTS}

\section{Basal organic matter sources}

Analysis of $\delta^{13} \mathrm{C}$ and $\delta^{15} \mathrm{~N}$ of basal organic matter sources revealed clearly discriminated isotopic signatures between SPOM (phytoplankton) $\left(\delta^{13} \mathrm{C}\right.$ : $\left.-20.23 \pm 0.21 \mathrm{SE}, \delta^{15} \mathrm{~N}: 4.83 \pm 0.06\right)$ and macroalgae (pooled) $\left(\delta^{13} \mathrm{C}:-12.21 \pm 0.70 ; \delta^{15} \mathrm{~N}: 7.11 \pm 0.33 ;\right.$ Fig. 2a). 

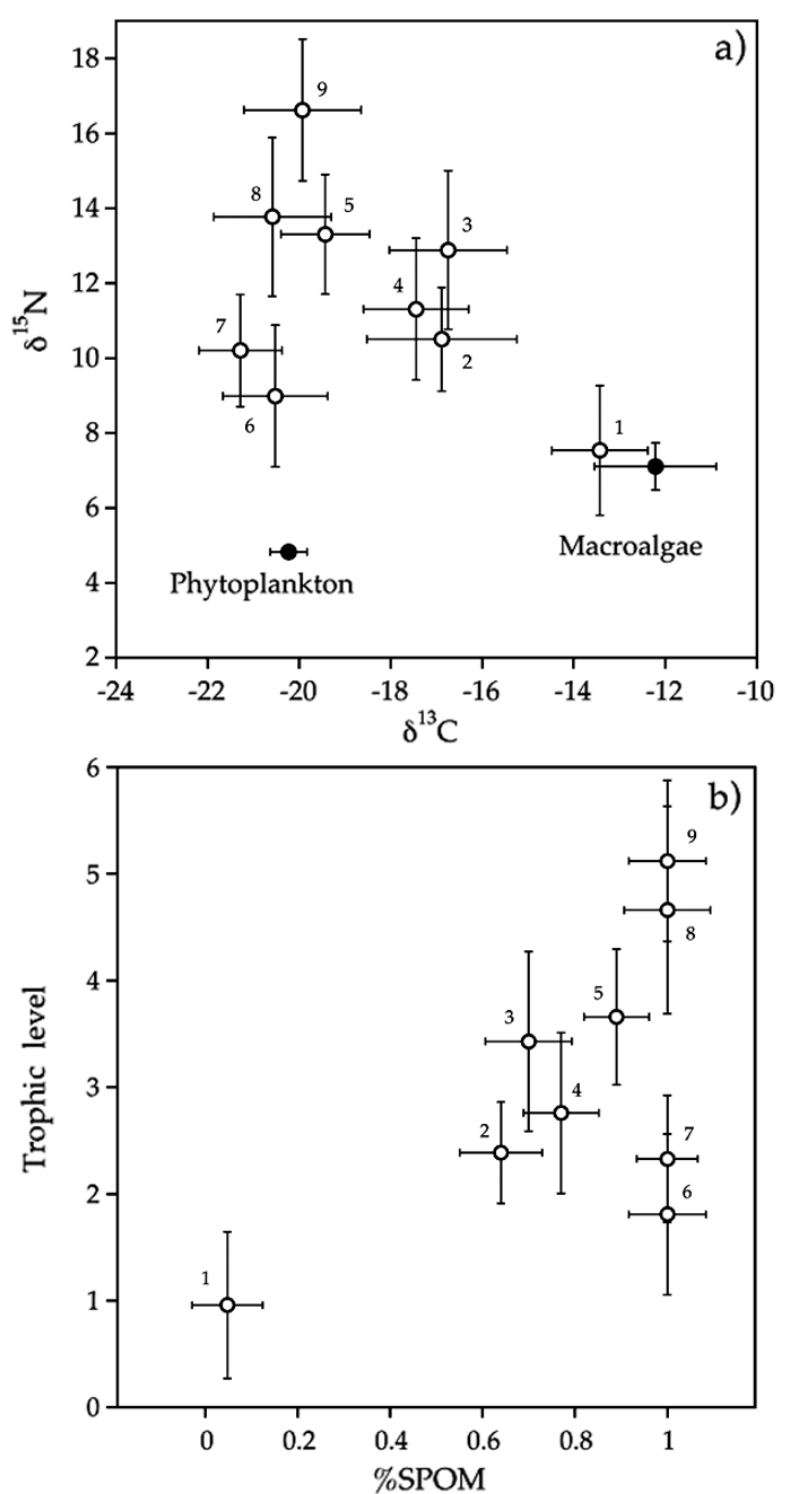

Fig. 2. (a) $\delta^{13} \mathrm{C}$ and $\delta^{15} \mathrm{~N}$ of guano and (b) 'trophic position' of seabirds and marine mammal diet; 1 : black-backed gull Larus dominicanus, 2: red-billed gull Chroicocephalus scopulinus, 3: brown skua Catharacta skua, 4: Auckland Island shag Phalacrocorax colensoi, 5: northern giant petrel Macronectes halli, 6: yellow-eyed penguin Megadypes antipodes, 7: southern right whale Eubalaena australis, 8: Hooker's sea lion Phocarctos hookeri, 9: southern royal albatross Diomedea epomophora. Error bars indicate $\pm 1 \mathrm{SE}$

\section{Analysis of $\delta^{13} \mathrm{C}$ and $\delta^{15} \mathrm{~N}$ among species and foraging guilds}

Both $\delta^{13} \mathrm{C}$ and $\delta^{15} \mathrm{~N}$ of guano differed among seabirds and marine mammals. $\delta^{13} \mathrm{C}$ was highest in the gull species of the coastal foraging guild and lowest in the oceanic foraging group and in marine mammals. (Full model: $\mathrm{r}^{2}=0.81, F_{8,39}=20.24, \mathrm{p}<0.0001$.
Foraging group: $F_{3,39}=34.35, \mathrm{p}<0.0001$, Tukey's post hoc test: coastal [a], predator [b], oceanic [c] mammal [c], where factor levels not sharing the same letters are significantly different. Species: $F_{5,39}=$ 7.89, $\mathrm{p}<0.0001$; Tukey's post hoc test: black-backed gull [a], brown skua [b], red-billed gull [bc], Auckland Island shag $[\mathrm{bc}]$, northern giant petrel [bcd], royal albatross [cd], yellow-eyed penguin [d], Hooker's sea lion [d], southern right whale [d]; Fig. 2a).

Results for the ANOVA on $\delta^{15} \mathrm{~N}\left(\mathrm{r}^{2}=0.62, F_{8,39}=\right.$ $7.78, \mathrm{p}<0.0001)$ showed differences among both foraging guilds $\left(F_{3,39}=5.87, \mathrm{p}<0.0021\right)$ and species $\left(F_{5,39}=8.69, \mathrm{p}<0.0001\right) . \delta^{15} \mathrm{~N}$ was lowest in guano of the black-backed gull in the coastal foraging guild and greatest in the oceanic forager royal albatross (Tukey's post hoc test for differences among foraging guilds: predator [a], oceanic [a], mammal [ab], coastal [b]; and among species: royal albatross [a], Hooker's sea lion [ab], northern giant petrel [ab], brown skua [ab], Auckland Island shag $[\mathrm{bc}]$, redbilled gull $[\mathrm{bc}]$, southern right whale $[\mathrm{bc}]$, yelloweyed penguin [bc], black-backed gull [c]; Fig. 2a).

\section{Trophic position}

Trophic level and the proportion of basal organic matter sources supporting food webs differed clearly among species. Among the coastal foragers, blackbacked gulls fed at a lower trophic level linked to macroalgal productivity, while Auckland Island shags and red-billed gulls occupied an intermediate position. The 2 predators, brown skua and northern giant petrel, fed at a higher trophic level and comprised a mixture of organic matter sources. The oceanic foragers relied on food webs fuelled by pelagic productivity, with southern royal albatross occupying a high trophic level and yellow-eyed penguins a lower trophic level. The 2 mammals were also linked to pelagic productivity, with southern right whales a secondary consumer and Hooker's sea lions feeding at a relatively high trophic level, consistent with prior knowledge of these species (Fig. 2b).

\section{Trace element concentrations}

Analysis of concentrations of $\mathrm{Fe}$ (ppm) from faeces and guano revealed clear differences among foraging guilds and species (full model: $\mathrm{r}^{2}=0.78, F_{7,33}=$ 16.91, p < 0.0001). [Fe] was higher in the guano of predatory birds than in other foraging guilds (foraging guild: $F_{3,33}=30.79, \mathrm{p}<0.0001$, Tukey's pairwise 

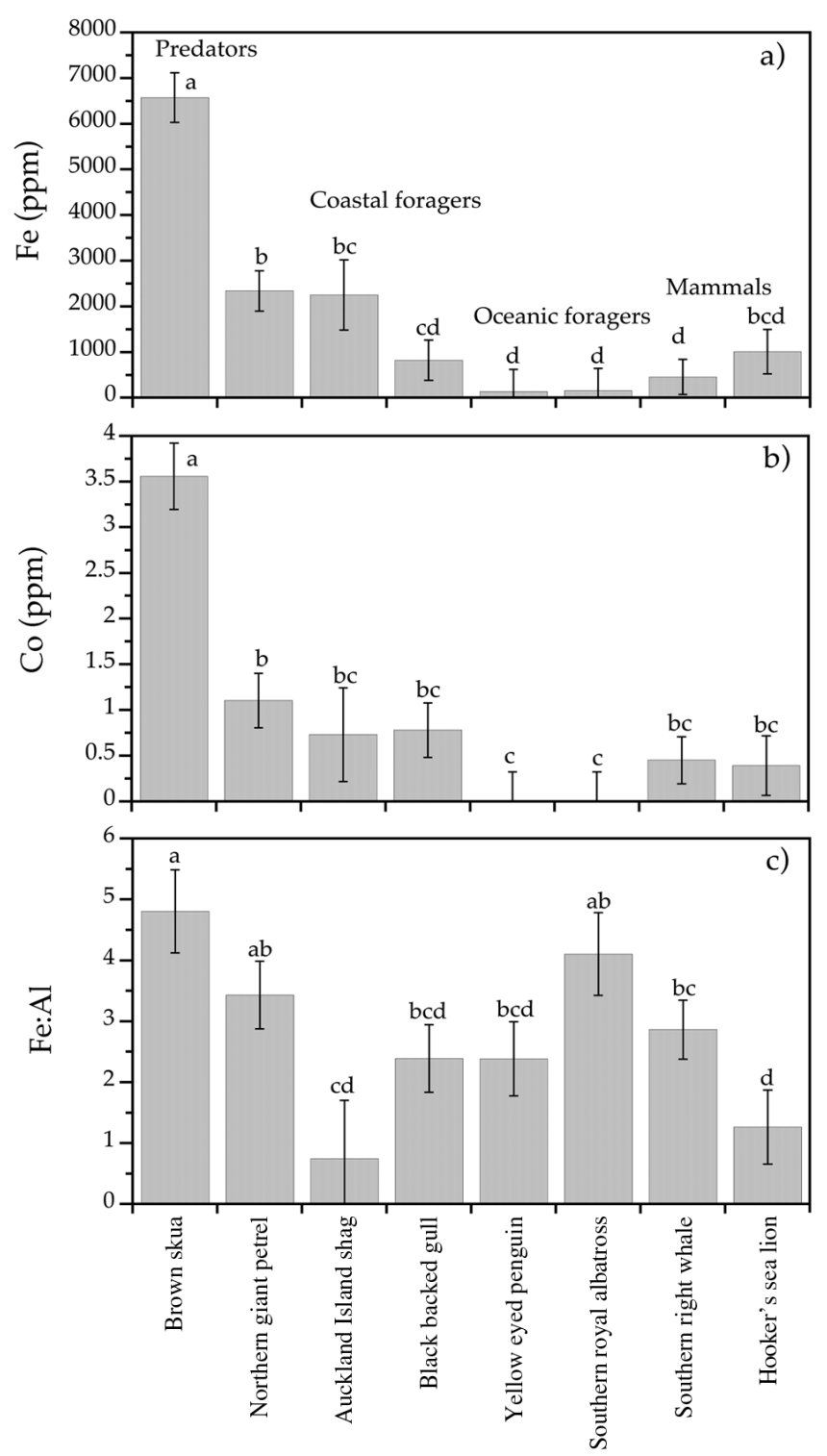

Fig. 3. Concentrations of (a) Fe ppm and (b) Co ppm in guano for each seabird and marine mammal species. (c) Molar ratio of Fe:Al. Bars that do not share the same letters are significantly different. Error bars indicate $\pm 1 \mathrm{SE}$

comparisons: predators [a], coastal, oceanic, mammal [b]) and was greatest in brown skua, whilst concentrations in the guano of oceanic foragers (yelloweyed penguins and southern royal albatross) were low (species: $F_{3,33}=9.99, \mathrm{p}<0.0001$; Fig. 3a).

Analysis of concentrations of Co (ppm) from faeces and guano revealed clear differences among foraging guilds and species (full model: $\mathrm{r}^{2}=0.69, F_{7,33}=$ $10.59, \mathrm{p}<0.0001$ ), with strikingly similar patterns in variability as those measured for [Fe]. [Co] was higher in the guano of predatory birds than in other foraging guilds $\left(F_{3,33}=19.29, \mathrm{p}<0.0001\right.$, Tukey's pairwise comparisons: predators [a], coastal, oceanic, mammal [b]) and was greatest in brown skua, whilst concentrations in the guano of oceanic foragers (yellow-eyed penguins and southern royal albatross) were low (species: $F_{3,33}=6.83, \mathrm{p}<0.0004$; Fig. $3 \mathrm{~b}$ ).

Ratios of Fe:Al from faeces and guano, a proxy for biological recycling of $\mathrm{Fe}$, also differed among foraging guilds and species (full model: $\mathrm{r}^{2}=0.45, F_{7,33}=$ $3.66, p=0.0052$ ). Fe:Al was higher in the guano of predatory birds than in other foraging guilds (foraging guild: $F_{3,33}=30.79, \mathrm{p}<0.0001$, Tukey's pairwise comparisons: predators [a], oceanic [ab], mammal $[\mathrm{bc}]$, coastal [c]), and was greatest in brown skua, whilst Fe:Al in the guano of coastal foragers (Auckland Islands shag) and marine mammals (especially Hooker's sea lion faeces) were low, suggesting fewer trophic steps between the lithogenic source of Fe and the diet of coastal species (species: $F_{3,33}=9.99, \mathrm{p}<$ 0.0001; Fig. 3c).

Ratios of Fe:C from faeces and guano, an indicator of bioaccumulation of Fe from the particulate pool, also differed among foraging guilds and species (full model: $\left.\mathrm{r}^{2}=0.68, F_{7,33}=10.16, \mathrm{p}<0.0001\right)$. Fe: $\mathrm{C}$ was greatest in the guano of predatory birds than in other foraging guilds (foraging guild: $F_{3,33}=15.99, \mathrm{p}<$ 0.0001, Tukey's post hoc test: predators [a], coastal [b], oceanic [c], mammal [bc]), in particular in brown skua, whilst the $\mathrm{Fe}: \mathrm{C}$ molar ratio in the guano of oceanic foragers and faeces of marine mammals, in particular yellow-eyed penguins and southern right whales, were low (species: $F_{3,33}=9.99, \mathrm{p}<0.0001$; Fig. 4a).

In addition, ratios of Fe: $\mathrm{N}$ differed among foraging guilds and species (full model: $\mathrm{r}^{2}=0.92, F_{7,31}=50.52$, $\mathrm{p}<0.0001$ ), indicating increases in the concentrations of Fe relative to $\mathrm{N}$ in the food web. Consistent with patterns in the ratio of $\mathrm{Fe}: \mathrm{C}, \mathrm{Fe}: \mathrm{N}$ ratios were highest in the guano of predatory species and lowest in oceanic foragers (foraging guild: $F_{3,33}=34.44, \mathrm{p}<$ 0.0001; Tukey's post hoc test: predators [a], coastal [b], oceanic [c], mammal [bc]). In particular, ratios of Fe:N were greatest in brown skua and relatively low in the oceanic foragers: yellow-eyed penguins and southern royal albatross (species: $F_{3,33}=77.92, \mathrm{p}<$ 0.0001; Fig. 4b).

Concentrations of Zn (ppm) and Mn (ppm) from guano and faeces also differed among foraging guilds and species. Zn concentrations (full model: $\mathrm{r}^{2}=$ $0.96, F_{7,30}=110.74, \mathrm{p}<0.0001$ ) were greatest in predatory foragers (foraging guild: $F_{3,33}=103.50, \mathrm{p}<$ 0.0001; Tukey's post hoc test: predators [a], coastal, oceanic, mammal [b]), a trend that appears driven by high levels found in the guano of brown skua (species: $F_{3,33}=107.81, \mathrm{p}<0.0001$; Fig. $5 \mathrm{a}$ ). Mn concen- 

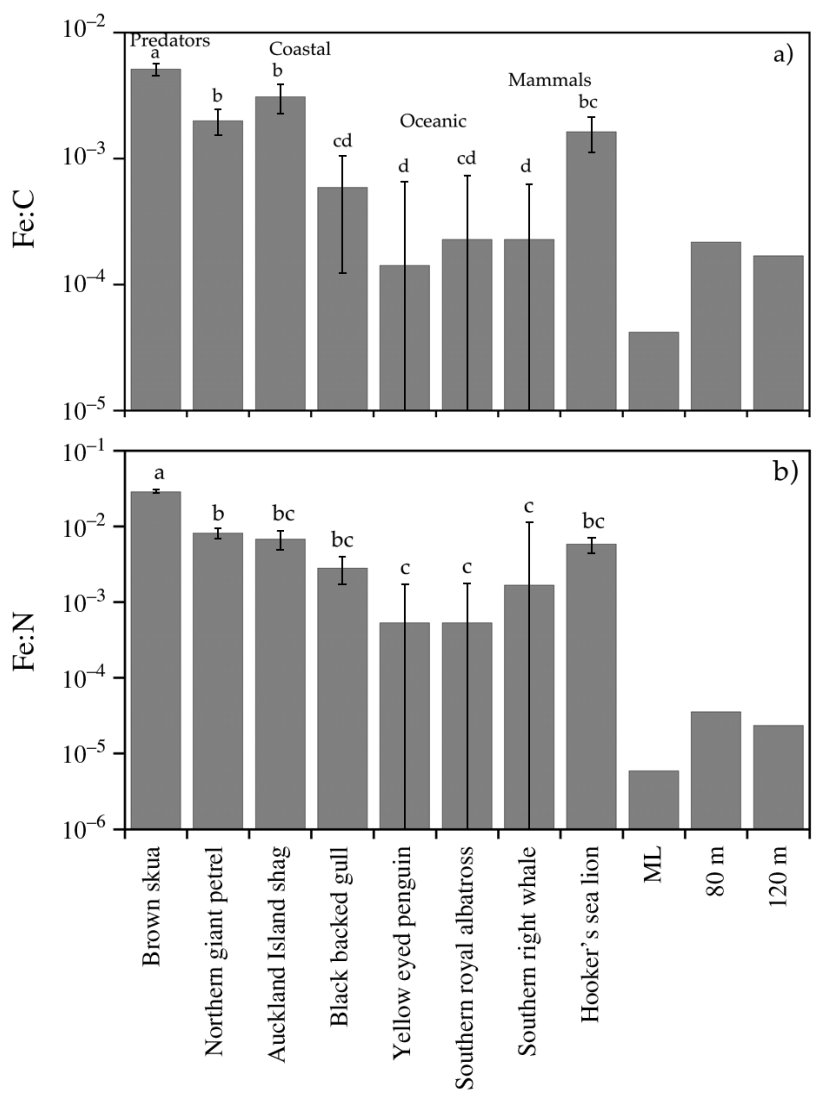

Fig. 4. Molar ratio of (a) Fe:C and (b) Fe:N in guano for each seabird and marine mammal species. Values for the molar ratios (Fe:C and $\mathrm{Fe}: \mathrm{N}$ ) of suspended particulate organic matter derived from sub-Antarctic water from mixed layer (ML), $80 \mathrm{~m}$ and $120 \mathrm{~m}$ are provided for reference (data from Frew et al. 2006). Bars that do not share the same letters are significantly different. Error bars indicate $\pm 1 \mathrm{SE}$

trations (full model: $\mathrm{r}^{2}=0.43, F_{7,33}=3.39, \mathrm{p}<0.008$ ) were similarly greatest in predatory foragers (foraging guild: $F_{3,33}=4.98, \mathrm{p}=0.006$, Tukey's post hoc test: predators [a], coastal, oceanic, mammal [b]), a trend similarly driven by high levels recorded in brown skua guano (species: $F_{3,33}=3.16, p<0.027$, Fig. 5a).

High concentrations of $\mathrm{Cd}$ (ppm) and As (ppm) were associated with the coastal food web. The concentration of $\mathrm{Cd}$ in guano and faeces (full model: $\mathrm{r}^{2}=$ $\left.0.88, F_{7,31}=33.46, \mathrm{p}<0.0001\right)$ was greatest in the guano of coastally foraging seabirds (foraging guild: $F_{3,31}=36.22, \mathrm{p}<0.0001$; coastal [a], predators, oceanic, mammal [b]), in particular in guano of black-backed gulls (species: $F_{4,31}=13.98, \mathrm{p}<0.0001$; Fig. $5 b$ ). Similarly concentrations of As in guano and faeces (full model: $\mathrm{r}^{2}=0.69, F_{7,32}=9.96, \mathrm{p}<0.0001$ ) were greatest in coastal foragers (foraging guild: $F_{3,32}=8.54, \mathrm{p}=$ 0.0003; Tukey's post hoc test: coastal [a], predators, oceanic, mammal [b]), in particular in guano of blackbacked gulls (species: $F_{4,32}=5.4, \mathrm{p}<0.002$; Fig. 5b).
We found positive linear relationships between $\delta^{13} \mathrm{C}$ versus $\mathrm{Cd}: \mathrm{C}$ and $\mathrm{As}: \mathrm{C}$, indicating a possible influence of organic matter source pool use on $[\mathrm{Cd}]$ and [As] in guano $\left(\mathrm{Cd}: \mathrm{C}_{;} \mathrm{r}^{2}=0.71, F_{1,6}=14.34, \mathrm{p}=0.0091\right.$, As: $C_{i} r^{2}=0.53, \quad F_{1,6}=6.79, p=0.040$; Fig. 6). Animals that were more reliant on food webs fuelled by macroalgae as an organic matter source had greater concentrations of $\mathrm{Cd}$ and $\mathrm{As}$ in their guano. No significant relationships were observed between $\delta^{13} \mathrm{C}$ and concentrations of $\mathrm{Fe}, \mathrm{Co}, \mathrm{Mn}$ or $\mathrm{Zn}$.

\section{DISCUSSION}

The data and results presented here demonstrate the potentially important role of seabirds and marine mammals as biological vectors of limiting nutrients in the sub-Antarctic ecosystem. In this system, Fe limitation restricts productivity in the offshore subAntarctic water mass, while coastal waters contain relatively high concentrations of Fe (Frew et al. 2006). In the present study, we report evidence for bioaccumulation of $\mathrm{Fe}$ in food webs supporting seabirds and marine mammals and note that relative to $\mathrm{N}, \mathrm{Fe}$ is accumulated in guano and faeces at 3 to 5 orders of magnitude higher concentrations than is needed for phytoplankton growth in sub-Antarctic water. Based on the concentrations that we have observed, the amount of bioavailable $\mathrm{Fe}$ in seabird guano and faeces of marine mammals may contribute a significant supply of recycled Fe to the upper mixed layer, needed to account for observed high pelagic production in the vicinity of the sub-Antarctic islands (Blain et al. 2008). For example, the average concentration of $\mathrm{Fe}$ in the guano of the coastally foraging group would account for a delivery of $0.016 \mathrm{~g}$ input of bioavailable Fe from $10 \mathrm{~g}$ dry weight (DW) of guano. Based on the observed $\mathrm{Fe}: \mathrm{C}$ molar requirement of phytoplankton in sub-Antarctic water in the range of $2.6 \times 10^{-5}$ to $4.2 \times 10^{-5} \mathrm{~mol} \mathrm{~mol}^{-1}$ (Boyd et al. 2004, Frew et al. 2006), this input would potentially facilitate production of 81.9 to $132.3 \mathrm{gC}$ from phytoplankton. After 1 trophic level in the pelagic food web, this would equate to 8.2 to $13.2 \mathrm{gC}$ from prey if birds were feeding at trophic level 2, for example on euphausiids (assuming a 10\% efficiency of organic matter transfer between trophic levels). This amount of prey approaches what is required for production of $10 \mathrm{~g}$ DW of guano. Thus the guano of coastally foraging seabirds in this system can potentially augment a significant component of the productivity needed to support their consumption of prey. 

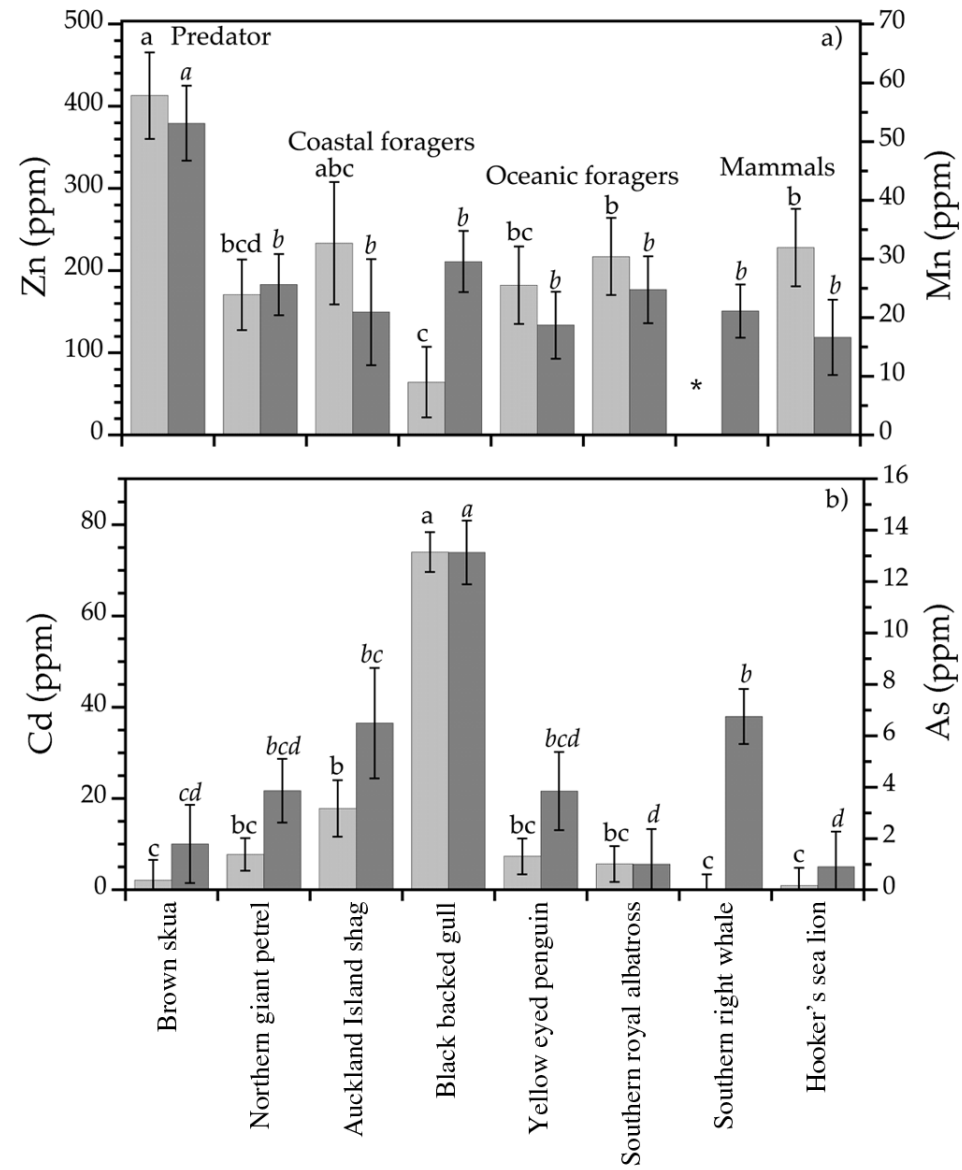

Fig. 5. Concentration of guano for each seabird and marine mammal species. (a) Zn (ppm), light grey; Mn (ppm), dark grey. (b) Cd (ppm), light grey; As (ppm), dark grey. Bars that do not share the same letters are significantly different (Roman type for light grey bars, italics for dark grey bars). ${ }^{*}$ indicates missing value. Error bars indicate $\pm 1 \mathrm{SE}$

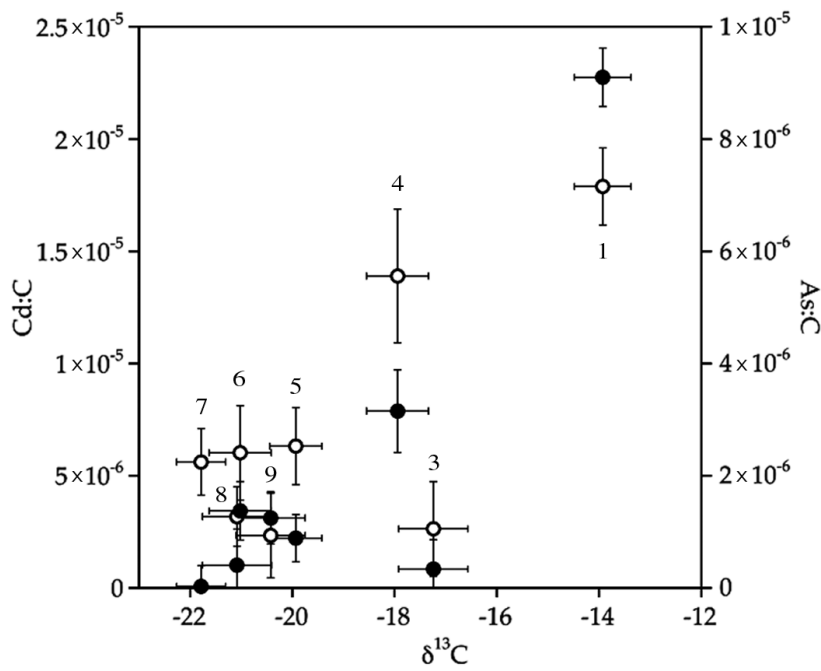

Fig. 6. Relationship between $\mathrm{Cd}: \mathrm{C}(\bullet), \mathrm{As}: \mathrm{C}(\mathbf{0})$ and $\delta^{13} \mathrm{C}$ of guano for seabirds and marine mammals. Error bars indicate \pm 1 SE. Numbers indicate species as identified in Fig. 2
The biological transport of nutrients associated with foraging can account for a significant portion of the nutrient budget in both aquatic (Meyer \& Schultz 1985) and terrestrial systems (Post et al. 1998, Wolf et al. 2013). Large-scale migrations associated with breeding in these systems have been observed to intensify biological pathways for nutrient transport. In this case, important fluxes of nutrients associated with breeding aggregations may dominate nutrient supply in some systems (Sánchez-Piñero \& Polis 2000, Helfield \& Naiman 2001). Results from the present study suggest an important ecological mechanism whereby bioaccumulation and redistribution of micronutrients within the food web may provide a positive feedback for supporting productivity in the vicinity of the sub-Antarctic islands.

Our data suggest 3 primary mechanisms by which marine mammals and seabirds potentially redistribute micronutrients in the subAntarctic ecosystem. First, in the oceanic realm, accumulation of Fe below the productive mixed layer has been observed in the sub-Antarctic water mass where Fe bound in phytoplankton, zooplankton and bacteria is transported into deeper water by the sinking of particles (Strzepek et al. 2005, Frew et al. 2006). Soluble Fe is required in minute amounts to stimulate pelagic productivity in the mixed layer of sub-Antarctic waters (Fe:C $4.2 \times 10^{-5}$ ) and is concentrated by an order of magnitude in the deep-scattering layer (Fe:C $2.2 \times 10^{-4}$; Frew et al. 2006). Additional flux of nutrients and organic matter may be driven by vertical migration of zooplankton and nekton that feed in the surface mixed layer by night and migrate to depth by day, where they excrete nutrient-rich wastes (Longhurst \& Harrison 1988). In the Southern Ocean, pelagic seabirds and marine mammals, such as southern royal albatross, yelloweyed penguins and southern right whales that feed extensively on deep scattering layer species, provide a mechanism for returning nutrients to the photic zone (e.g. Lavery et al. 2010). In the present study, we observed high Fe:Al molar ratios within the guano of this foraging guild, indicating extensive recycling of Fe within the food web (Frew et al. 2006). Our data suggest that oceanic foragers provide guano that is rich in Fe relative to concentrations in the surface waters. For example we observed molar ratios of Fe:N 2 orders of magnitude higher in guano of oceanic foragers than those found in the mixed layer of subAntarctic waters (Frew et al. 2006). 
A second mechanism is the likely horizontal redistribution of nutrients by coastally foraging species, such as Auckland Island shag, black-backed gull and Hooker's sea lion. These species feed within relatively micronutrient-rich coastal food webs and extend their foraging bouts across the island shelf in proximity to the most Fe-limited waters. Concentrations of Fe and other potentially limiting micronutrients are markedly higher in the island wakes of the sub-Antarctic islands than in surrounding oceanic water, a gradient in concentration that can exceed 3 orders of magnitude (Blain et al. 2001). These gradients in the availability of Fe are reflected in adaptations of oceanic diatoms to Fe-depleted conditions relative to coastal species (Strzepek \& Harrison 2004). Coastally feeding seabirds and marine mammals frequently make foraging bouts to frontal zones and the edges of the continental margin. In the subAntarctic islands, this region comprises the island shelf and associated waters. Based on our data, the coastal foraging guild accumulates high concentrations of Fe and other potentially limiting micronutrients (Co, Zn, Mn) and transports them during extended foraging bouts across horizontal gradients in micronutrient supply. Here our analysis indicates that accumulation of Fe relative to $N$ (Fe:N) in the guano of the coastal foragers can reach 3 orders of magnitude above that required for phytoplankton growth in sub-Antarctic waters, indicating a strong potential gradient between coastal foragers and the offshore photic zone. Our analysis of the trophic position of these foragers indicates that they rely on food webs fuelled by a mixture of coastal macroalgae and phytoplankton and range in trophic level from 2 to 4 , highlighting the potential of these species to integrate micronutrients from multiple organic matter sources.

The third mechanism for the potential redistribution of $\mathrm{Fe}$, and other limiting micronutrients, is the trophic magnification of micronutrients by top predators and scavengers. The predatory guild is represented in the present study by the brown skua, a specialist predator on seabirds, and by the northern giant petrel, an opportunistic predator-scavenger. As a predatory guild, these high trophic level (4-5) consumers feed on both coastal (Auckland Island shags, black-backed gulls) and oceanic seabirds (storm petrels, prions) and on carrion from marine mammals and seabirds. Their diet therefore includes micronutrient-rich components, and because they feed widely across the coastal system extending out to oceanic fronts, they potentially accumulate and then redistribute these trace metals across strong horizontal gradients. Top predatory seabirds have the highest observed accumulations of micronutrients in their guano, with concentrations of Fe of up to $8.84 \mathrm{mg} \mathrm{g}^{-1}$, or a molar ratio Fe: $\mathrm{N}$ of 0.025 , found in guano of brown skuas. The Fe: $\mathrm{N}$ in this guano is 4 orders of magnitude above reported ambient conditions in the sub-Antarctic mixed-layer particulate pool, indicating a high potential for lateral diffusion of nutrients (Fig. 4). By integrating across foraging guilds and consuming a micronutrient-rich diet, predators and scavengers provide a focal point for redistribution of high concentrations of bioavailable Fe in this system.

An additional pattern observed in our analysis is the covariability of As and Cd concentrations in the guano of seabirds. We observed the highest concentrations of both As and Cd in the guano of blackbacked gulls, which feed extensively in the intertidal zone on prey such as mussels, crabs and limpets. Analysis of the trophic position of black-backed gulls indicated reliance on food webs founded largely on macroalgae as the basal organic matter source. The observed pattern indicates that $\mathrm{As}$ and $\mathrm{Cd}$ may be sourced from organic matter originating from kelp, which can contain high concentrations of both As and Cd in this system (e.g. Walsh \& Hunter 1992). These data highlight the interaction between food web structure, composition of basal organic matter sources and the accumulation of bioactive trace metals in the system.

The patterns reported here highlight the possibility that a small component of the biological community may play a large role in the lateral diffusion of limiting nutrients. The amount of transport by each of these mechanisms will depend strongly on the size and composition of seabird and marine mammal populations. Presently, best estimates for global consumption of food by seabirds are approximately 96.4 $\mathrm{Mt} \mathrm{yr}^{-1}$ (Brooke 2004, Karpouzi et al. 2007). Similarly, marine mammals may consume approximately 150.7 $\mathrm{Mt} \mathrm{yr}^{-1}$ in the Pacific Ocean (Trites et al. 1997, Pauly et al. 1998). Therefore, together seabirds and marine mammals require approximately $22 \%$ of primary production in order to maintain current population sizes (Pauly \& Christensen 1995, Trites et al. 1997). The associated nutrients from this consumption are both recycled and, importantly, redistributed across the system against oceanographic concentration gradients. At present, both seabird and marine mammal population densities in the Southern Ocean are at historical lows, suggesting scope for a potentially much larger role of both groups as nutrient vectors (e.g. Nicol et al. 2010, Lavery et al. 2014). 
Although the data presented here support the possibility that seabirds and marine mammals act as biological vectors, several caveats must accompany these conclusions. Our study focused on individual samples of seabird guano and faeces of marine mammals, so conclusions about trophic level and composition of organic matter sources are based on the most recent meal of individuals rather than an integrated measure of diet. Accordingly, information on trophic position is then constrained to the breeding season for these animals when they form aggregations on the island. We took special care to collect fresh samples and identify individuals so sample sizes would reflect population variability. Also, fresh samples would not be subject to significant volatilisation of ammonia and associated influences on $\delta^{15} \mathrm{~N}$. Nevertheless, direct comparisons of $\delta^{15} \mathrm{~N}$ in mammal faeces with those in guano of birds are somewhat problematic because bird guano contains egested material as well as excreted urine deplete of ${ }^{15} \mathrm{~N}$. We therefore used estimates of trophic position in the present study to augment information on the foraging behavior of each species; however, our a priori groupings are based on trophic studies of each species (see 'Focal species' in 'Materials and methods'). Data on concentrations of $\mathrm{Fe}$ and other bioactive trace metals provide important evidence for bioaccumulation of these micronutrients within food webs supporting the 4 feeding guilds. Here we specifically contrasted seabirds that forage in the coastal zone with those that make extensive oceanic foraging bouts. We then considered seabird predators and carrion feeders as a separate category. Concentrations of micronutrients in these guilds were compared to those found in the faeces of Hooker's sea lions and southern right whales, 2 important marine mammals on the Auckland Islands. We did not resolve mechanisms for bioaccumulation in these food webs; however, these data give important clues for how micronutrients are distributed within coastal and oceanic food webs.

Seabird populations are important indicators of the marine food web (Jenouvrier et al. 2005b, Piatt et al. 2007), varying in distribution and abundance with sea surface temperature (Weimerskirch et al. 2003), prey stocks (Croxall et al. 2002) and shifts in ecosystem processes (Croxall et al. 2002, Jenouvrier et al. 2005a). For example, on the sub-Antarctic islands, declines in the abundance of rockhopper penguins Eudyptes chrysocome coincide with stable isotopic evidence of declines in regional productivity (Hilton et al. 2006). Loss of seabird abundance and diversity would alter the link between seabirds and nutrient dynamics around the sub-Antarctic islands. This may have important consequences for oceanic productivity at these hotspots for Southern Ocean biodiversity. Our results highlight an ecological mechanism whereby changes in population densities of seabirds and marine mammals may influence patterns in productivity in the system. This mechanism has important consequences for how the system may respond to loss of top trophic level species and the ecosystem services that they provide as nutrient vectors. Restoration of populations of these critical species may result in enhanced lateral diffusion of nutrients in the vicinity of islands and gains in productivity in the sub-Antarctic ecosystem.

Acknowledgements. We thank Will Rayment, Peter McClelland, Robert Van Hale, Bill Dickson, C. Lalas, Clive Hesseltine and Steve Little for valuable contributions to this research. Support was provided from New Zealand's Department of Conservation, the University of Otago Research Committee and from the Royal Society of New Zealand's Marsden Fund (UOO1008).

\section{LITERATURE CITED}

Behrenfeld MJ, Kolber ZS (1999) Widespread iron limitation of phytoplankton in the South Pacific Ocean. Science 283:840-843

Bernardi E, Bowden D, Brimblecombe P, Kenneally $\mathrm{H}$, Morselli L (2009) The effect of uric acid on outdoor copper and bronze. Sci Total Environ 407:2383-2389

> Best P, Schell D (1996) Stable isotopes in southern right whale (Eubalaena australis) baleen as indicators of seasonal movements, feeding and growth. Mar Biol 124: 483-494

Blain S, Tréguer P, Belviso S, Bucciarelli E and others (2001) A biogeochemical study of the island mass effect in the context of the iron hypothesis: Kerguelen Islands, Southern Ocean. Deep-Sea Res I 48:163-187

Blain S, Quéguiner B, Armand L, Belviso S and others (2007) Effect of natural iron fertilization on carbon sequestration in the Southern Ocean. Nature 446:1070-1074

- Blain S, Sarthou G, Laan P (2008) Distribution of dissolved iron during the natural iron-fertilization experiment KEOPS (Kerguelen Plateau, Southern Ocean). Deep-Sea Res II 55:594-605

- Bosman A, Du Toit J, Hockey P, Branch G (1986) A field experiment demonstrating the influence of seabird guano on intertidal primary production. Estuar Coast Shelf Sci 23:283-294

Boyd PW, Law CS, Wong CS, Nojiri Y and others (2004) The decline and fate of an iron-induced subarctic phytoplankton bloom. Nature 428:549-553

Boyd PW, Jickells T, Law CS, Blain S and others (2007) Mesoscale iron enrichment experiments 1993-2005: synthesis and future directions. Science 315:612-617

Boyd PW, Mackie DS, Hunter KA (2010) Aerosol iron deposition to the surface ocean-modes of iron supply and biological responses. Mar Chem 120:128-143

Brooke M (2004) The food consumption of the world's sea- 
birds. Proc R Soc Lond B Biol Sci 271:S246-S248

Childerhouse S, Gales N (1998) Historical and modern distribution and abundance of the New Zealand sea lion Phocarctos hookeri. N Z J Zool 25:1-16

- Coale KH, Johnson KS, Chavez FP, Buesseler KO and others (2004) Southern Ocean iron enrichment experiment: carbon cycling in high- and low-Si waters. Science 304: 408-414

Croll DA, Maron JL, Estes JA, Danner EM, Byrd GV (2005) Introduced predators transform subarctic islands from grassland to tundra. Science 307:1959-1961

Croxall JP, Trathan PN, Murphy EJ (2002) Environmental change and Antarctic seabird populations. Science 297: 1510-1514

> Doughty C, Wolf A, Malhi Y (2013) The legacy of the Pleistocene megafauna extinctions on nutrient availability in Amazonia. Nat Geosci 6:761-764

- Evenset A, Carroll J, Christensen G, Kallenborn R, Gregor D, Gabrielsen G (2007) Seabird guano is an efficient conveyer of persistent organic pollutants (POPs) to Arctic lake ecosystems. Environ Sci Technol 41:1173-1179

> Frew R, Hutchins D, Nodder S, Sanudo-Wilhelmy S, TovarSanchez A, Boyd P (2006) Particulate iron dynamics during FeCycle in subantarctic waters SE of New Zealand. Global Biogeochem Cycles 20:GB1S93, doi:10.1029/2005 GB002558

> Hawke D, Holdaway R (2005) Avian assimilation and dispersal of carbon and nitrogen brought ashore by breeding Westland petrels (Procellaria westlandica): a stable isotope study. J Zool 266:419-426

> Helfield J, Naiman R (2001) Effects of salmon-derived nitrogen on riparian forest growth and implications for stream productivity. Ecology 82:2403-2409

Hilton G, Thompson D, Sagar P, Cuthbert R, Cherel Y, Bury $\mathrm{S}$ (2006) A stable isotopic investigation into the causes of decline in a sub-Antarctic predator, the rockhopper penguin Eudyptes chrysocome. Glob Change Biol 12: 611-625

Imber M (1999) Diet and feeding ecology of the Royal Albatross Diomedea epomophora-king of the shelf break and inner slope. Emu 99:200-211

> Jack L, Wing SR (2011) Individual variability in trophic position and diet of a marine omnivore is linked to kelp bed habitat. Mar Ecol Prog Ser 443:129-139

> Jenouvrier S, Weimerskirch H, Barbraud C, Park Y, Cazelles B (2005a) Evidence of a shift in the cyclicity of Antarctic seabird dynamics linked to climate. Proc R Soc Lond B Biol Sci 272:887-895

Jenouvrier S, Barbraud C, Weimerskirch H (2005b) Longterm contrasted responses to climate of two Antarctic seabird species. Ecology 86:2889-2903

> Jickells TD, An ZS, Anderson KK, Baker AR and others (2005) Global iron connections between desert dust, ocean biogeochemistry, and climate. Science 308:67-71

Karpouzi VS, Watson R, Pauly D (2007) Modelling and mapping resource overlap between seabirds and fisheries on a global scale: a preliminary assessment. Mar Ecol Prog Ser 343:87-99

Keatley B, Douglas M, Blais J, Mallory M, Smol J (2009) Impacts of seabird-derived nutrients on water quality and diatom assemblages from Cape Vera, Devon Island, Canadian High Arctic. Hydrobiologia 621:191-205

Kooyman GL, Ponganis PJ (1998) The physiological basis of diving to depth. Annu Rev Physiol 60:19-32

> La Roche J, Boyd P, McKay R, Geider R (1996) Flavodoxin as an in situ marker for iron stress in phytoplankton. Nature 382:802-805

Lalas C (1997) Prey of Hooker's sea lions, Phocarctos hookeri, based at Otago Peninsula, New Zealand. In: Hindell MA, Kemper C (eds) Marine mammal research in the southern hemisphere, Vol 1. Status, ecology, and medicine. Surrey Beatty and Sons, Ltd., Chipping Norton, p 130-136

Lavery TJ, Roudnew B, Gill P, Seymour J and others (2010) Iron defecation by sperm whales stimulates carbon export in the Southern Ocean. Proc R Soc Lond B Biol Sci 277:3527-3531

Lavery TJ, Roudnew B, Seymour J, Mitchell JG, Smetacek V, Nicol S (2014) Whales sustain fisheries: blue whales stimulate primary production in the Southern Ocean. Mar Mamm Sci 30:888-904

> Lock JW, Thompson DR, Furness RW, Bartle JA (1992) Metal concentrations in seabirds of the New Zealand region. Environ Pollut 75:289-300

> Long S, Skadhauge E (1983) The role of urinary precipitates in the excretion of electrolytes and urate in the domestic fowl. J Exp Biol 104:41-50

> Longhurst A, Harrison W (1988) Vertical nitrogen flux from the oceanic photic zone by diel migrant zooplankton and nekton. Deep-Sea Res 35:881-889

Mackie DS, Boyd PW, McTainsh GH, Tindale NW, Westberry TK, Hunter KA (2008) Biogeochemistry of iron in Australian dust: from eolian uplift to marine uptake. Geochem Geophys Geosyst 9:Q03Q08, doi:10.1029/2007 GC001813

McCauley DJ, DeSalles PA, Young HS, Dunbar RB, Dirzo R, Mills MM, Micheli F (2012) From wing to wing: the persistence of long ecological interaction chains in lessdisturbed ecosystems. Sci Rep 2:409

McCutchan JH Jr, Lewis WM Jr, Kendall C, McGrath CC (2003) Variation in trophic shift for stable isotope ratios of carbon, nitrogen, and sulfur. Oikos 102:378-390

> Meyer J, Schultz E (1985) Migrating haemulid fishes as a source of nutrients and organic matter on coral reefs. Limnol Oceanogr 30:146-156

- Nicol S, Bowie A, Jarman S, Lannuzel D, Meiners K, van der Merwe P (2010) Southern ocean iron fertilization by baleen whales and Antarctic krill. Fish Fish 11:203-209

Norheim G (1987) Levels and interactions of heavy metals in sea birds from Svalbard and the Antarctic. Environ Pollut 47:83-94

Pauly D, Christensen V (1995) Primary production required to sustain global fisheries. Nature 374:255-257

Pauly D, Trites A, Capuli E, Christensen V (1998) Diet composition and trophic levels of marine mammals. ICES J Mar Sci 55:467-481

Pauly D, Christensen V, Guénette S, Pitcher TJ and others (2002) Towards sustainability in world fisheries. Nature 418:689-695

> Phillips DL, Gregg JW (2001) Uncertainty in source partitioning using stable isotopes. Oecologia 127:171-179

Piatt JF, Sydeman WJ, Wiese F (2007) Introduction: a modern role for seabirds as indicators. Mar Ecol Prog Ser 352: 199-204

Pietz P (1987) Feeding and nesting ecology of sympatric south polar and brown skuas. Auk 104:617-627

> Polis G, Hurd S (1996) Linking marine and terrestrial food webs: Allochthonous input from the ocean supports high secondary productivity on small islands and coastal land communities. Am Nat 147:396-423 
Polis G, Anderson W, Holt R (1997) Toward an integration of landscape and food web ecology: the dynamics of spatially subsidized food webs. Annu Rev Ecol Syst 28: 289-316

Post D (2002) Using stable isotopes to estimate trophic position: models, methods, and assumptions. Ecology 83: 703-718

Post D, Taylor J, Kitchell J, Olson M, Schindler D, Herwig B (1998) The role of migratory waterfowl as nutrient vectors in a managed wetland. Conserv Biol 12:910-920

Ridoux V (1994) The diets and dietary segregation of seabirds at the subAntarctic Crozet Islands. Mar Ornithol 22:65-128

Sánchez-Piñero F, Polis G (2000) Bottom-up dynamics of allochthonous input: direct and indirect effects of seabirds on islands. Ecology 81:3117-3132

Smith R, Vennell R, Bostock H, Williams M (2013) Interaction of the subtropical front with topography around southern New Zealand. Deep-Sea Res I 76:13-26

Strzepek RF, Harrison PJ (2004) Photosynthetic architecture differs in coastal and oceanic diatoms. Nature 431: 689-692

Strzepek RF, Maldonado MT, Higgins JL, Hall J, Safi K, Wilhelm SW, Boyd PW (2005) Spinning the 'Ferrous Wheel':

Editorial responsibility: Jacob González-Solís,

Barcelona, Spain the importance of the microbial community in an iron budget during the FeCycle experiment. Global Biogeochem Cycles 19:GB4S26, doi:10.1029/2005GB002490

> Trites A, Christensen V, Pauly D (1997) Competition between fisheries and marine mammals for prey and primary production in the Pacific Ocean. J Northwest Atl Fish Sci 22:173-187

van Heezik Y (1990) Seasonal, geographical, and agerelated variations in the diet of the yellow-eyed penguin (Megadyptes antipodes). N Z J Zool 17:201-212

Walsh R, Hunter K (1992) Influence of phosphorus storage on the uptake of cadmium by the marine alga Macrocystis pyrifera. Limnol Oceanogr 37:1361-1369

Waugh S, Filippi D, Fukuda A, Suzuki M, Higuchi H, Setiawan A, Davis L (2005) Foraging of royal albatrosses, Diomedea epomophora, from the Otago Peninsula and its relationships to fisheries. Can J Fish Aquat Sci 62: 1410-1421

Weimerskirch H, Inchausti P, Guinet C, Barbraud C (2003) Trends in bird and seal populations as indicators of a system shift in the Southern Ocean. Antarct Sci 15:249-256

> Wolf A, Doughty C, Malhi Y (2013) Lateral diffusion of nutrients by mammalian herbivores in terrestrial ecosystems. PLoS ONE 8:e71352

Submitted: April 9, 2014; Accepted: June 20, 2014 Proofs received from author(s): July 25, 2014 